Kiss and Tell 



\section{Kiss and Tell}

SURVEYING SEX IN THE TWENTIETH CENTURY

\section{JULIA A. ERICKSEN}

WITH SALLY A. STEFFEN 
Copyright $\odot 1999$ by the President and Fellows of Harvard College All rights reserved

Printed in the United States of America

First Harvard University Press paperback edition, 2006

Library of Congress Cataloging-in-Publication Data

Ericksen, Julia, A., 1941-

Kiss and tell : surveying sex in the twentieth century /

Julia A. Ericksen with Sally A. Steffen.

p. $\mathrm{cm}$.

Includes bibliographical references and index.

ISBN 0-674-50535-2 (alk. paper)

ISBN 0-674-00695-X (pbk.)

1. Sexual behavior surveys-United States. 2. Sexology-United States-History-20th century. 3. Sex customs-United States. I. Steffen, Sally A. II. Title.

HQ18.U5E75 1999

$306.7^{\prime} 0973^{\prime} 0904-\mathrm{dc} 21 \quad 98-38990$ 
To the hundreds of men and women who undertook surveys in the belief that the truth about sex can set us free 
